\title{
Chapter 6 \\ Didactics of Mathematics as a Research Field in Scandinavia
}

\author{
Frode Rønning
}

\begin{abstract}
This chapter presents an overview of the development of didactics of mathematics as a research domain in the three Scandinavian countries, Denmark, Norway and Sweden. This presentation is linked to the development of the school system and teacher education. Some important trends that have been of particular importance to each of the countries will be described and an account of the current situation will be given. At the end there is a section about collaborative projects that have taken place in the whole Nordic and Baltic area.
\end{abstract}

Keywords Competencies - Critical mathematics education - Didactics of mathematics $\cdot$ Mathematical modelling $\cdot$ Mathematics and democracy • Scandinavia

\subsection{Introduction}

In this chapter I will present some important aspects of didactics of mathematics as a research field in the three countries of Denmark, Norway and Sweden. The term didactics of mathematics corresponds to the terms used in the national languages about the research field: matematikdidaktik in Danish and Swedish and matematikkdidaktikk in Norwegian. These terms correspond to mathematics education in English. I will use the term mathematics education when I refer to the enterprise where teaching and learning of mathematics takes place. It will not be possible to cover the topic in full within the scope of the chapter, so what is presented will not be an exhaustive account of all activity. I have based my presentation on available literature, existing webpages, information that colleagues have kindly provided for me upon request and my own knowledge of the situation.

I will refer to Denmark, Norway and Sweden as the Scandinavian countries. These three countries share many similarities, both in the ways the societies are organised and the values that are shared in areas such as democracy, equality and equity. In

\footnotetext{
F. Rønning ( $ه)$

Department of Mathematical Sciences, Norwegian University

of Science and Technology, 7491 Trondheim, Norway

e-mail: frode.ronning@ntnu.no

(C) The Author(s) 2019

W. Blum et al. (eds.), European Traditions

in Didactics of Mathematics, ICME-13 Monographs,

https://doi.org/10.1007/978-3-030-05514-1_6
} 
the way the school systems and teacher education are organised one can also find many similarities between the three countries. Since didactics of mathematics is linked closely to both school system and teacher education, it is natural that the research field also shares many features across the countries. An aspect of some relevance is also that the languages in the three countries are very similar and can in general be used across the borders without major difficulties. Collaboration in the region very often also includes Iceland and Finland, which, together with Norway, Sweden and Denmark form the Nordic countries. In recent years, this collaboration has increasingly also included the Baltic states (Estonia, Latvia and Lithuania). My main presentation will not include Finland, Iceland and the Baltic states. However, there are important events and institutions where it is obvious that they should be included. The final section of the chapter is dedicated to an account of these.

After the Introduction (Sect. 6.1), I will present some historical background (Sect. 6.2) and then give a presentation of the early development of didactics of mathematics as a research field in Scandinavia (Sect. 6.3). Sections 6.4, 6.5 and 6.6 will present further development and more recent activity in the countries Denmark, Norway and Sweden, respectively (presented in alphabetical order). Finally, Sect. 6.7 is devoted to common initiatives covering the whole Nordic and Baltic region.

Earlier attempts to give an overview of research in the Nordic region have been made, for example, by Björkqvist (2003a), who made a list of research problems in Nordic research on didactics of mathematics. The items from this list that are most relevant for the Scandinavian countries are presented below.

- Research on realistic problem solving in mathematics

- Research on problem solving as an example of school mathematics as situated practice

- Research on connecting the teaching of mathematics in elementary schools to everyday experiences

- Research on the role of mathematics education in society and the political dimensions of mathematics education

- Research on the effects of the hand-held calculators in mathematics education in elementary school

- Research with a strong emphasis on understanding children with special difficulties in mathematics

- Research in the phenomenographic paradigm

- Research on mathematical misconceptions and common errors in school mathematics

- Research on strategies of students solving mathematical problems

- Research on mathematical operativity

- Research on women and mathematics (Björkqvist, 2003a).

In another report, where Björkqvist was commissioned to do a survey of research in the field in Sweden (Björkqvist, 2003b), he mentions some areas that he finds to be particularly prominent in Sweden. Two of these areas are phenomenographic research and research on mathematics and democracy. Mathematics and democracy is also an important field in the two other Scandinavian countries. I will discuss these and some other areas in some detail later. Björkqvist's reports may have presented a 
Table 6.1 Research paradigms

\begin{tabular}{l|l|l|l}
\hline & ESM & JRME & NOMAD \\
\hline $\begin{array}{l}\text { Studies of learning and cognition, including problem-solving } \\
\text { strategies }\end{array}$ & 10 & 6 & 5 \\
\hline $\begin{array}{l}\text { Studies of outcomes of interventions, including teaching } \\
\text { approaches and experiments }\end{array}$ & 5 & 8 & 2 \\
\hline $\begin{array}{l}\text { Suggesting and implementing theoretical/analytic constructs or } \\
\text { frameworks }\end{array}$ & 7 & 1 & 3 \\
\hline $\begin{array}{l}\text { Uncovering beliefs, attitudes, affects or identities with teachers } \\
\text { and students }\end{array}$ & 6 & 0 & 4 \\
\hline
\end{tabular}

Table 6.2 Methodological approaches

\begin{tabular}{l|l|l|l}
\hline & ESM & JRME & NOMAD \\
\hline $\begin{array}{l}\text { Conceptual and theoretical } \\
\text { investigations }\end{array}$ & 10 & 1 & 3 \\
\hline $\begin{array}{l}\text { Qualitative empirical } \\
\text { investigations }\end{array}$ & 22 & 10 & 7 \\
\hline $\begin{array}{l}\text { Quantitative empirical } \\
\text { investigations }\end{array}$ & 6 & 6 & 7 \\
\hline
\end{tabular}

fair description of the activity up to 2003, but, as will become clear later, the activity has increased tremendously, so a similar list 15 years later would have become much longer and more diverse. Also, some of the areas on Björkqvist's list may not be so important anymore.

It is hard to identify any dominating theories or paradigms in Scandinavian research, although some commonalities can be seen. Mogens Niss attempted to do a quantification of preferred research study paradigms and choices of methods in didactics of mathematics to see whether the Nordic countries stood out in any way from the rest of the world (Niss, 2013). He picked all papers published from April 2011 to April 2012 from three journals, Educational Studies in Mathematics (ESM), Journal for Research in Mathematics Education (JRME) and Nordic Studies in Mathematics Education (NOMAD), ${ }^{1}$ and classified each paper as belonging to one of 10 research paradigms and using one of three methodological approaches. The total number of papers came to 72: 38 in ESM and 17 each in JRME and NOMAD. In the ESM and JRME papers, three Nordic authors were involved and in the NOMAD papers one non-Nordic author was involved. The results from this classification might give an idea about which paradigms or methods are particularly dominant in the Nordic area. $^{2}$ Table 6.1 shows the results on research paradigms presented by Niss, including only the four paradigms that were represented with 10 or more papers. Table 6.2 shows the identified methodological approaches.

\footnotetext{
${ }^{1}$ A journal for the Nordic and Baltic region (see Sect. 6.7).

${ }^{2}$ Niss did not distinguish between Scandinavia and the rest of the Nordic/Baltic region.
} 
That the number of papers in ESM was a little more than twice the number of papers in each of the two other journals indicates that, for example, the topic of beliefs and attitudes is overrepresented in NOMAD compared to the two other journals and that intervention studies is somewhat underrepresented. Also, conceptual and theoretical investigations are clearly underrepresented. The overrepresentation in beliefs and attitudes can be explained by the fact that NOMAD published a thematic issue on belief research during this period (Vol. 16, No. 1-2, June 2011). This issue contained five articles, four of which Niss categorised under this research paradigm. It is also worth mentioning that belief research has for a long time had a particularly strong position in Finland. Researchers from Finland have kept a close connection to the Mathematical Views (MAVI) group (Pehkonen, 2012), and indeed there was another thematic issue of NOMAD (Vol. 17, No. 3-4, December 2012) on this topic published shortly after the period covered by Niss (2013) in his survey.

The results presented in Tables 6.1 and 6.2 come from a small set of data, so one cannot draw strong conclusions from them, but they may give an indication of what kind of research has been in focus in the chosen period. Regarding the issue of nearness to mathematics, there is great variation, both between the countries and within the countries. Some of the research has come out of departments of education, where the subject may not be so much in focus and where the leading researchers have their main background in general education (pedagogy). It may seem that nearness to mathematics in the research has become stronger in recent years and that the activity in didactics at departments of mathematics has been increasing. Most of the research has been empirical and has had a close connection to the classroom and/or to teacher education. This reflects the fact that most of the research on didactics of mathematics has grown out of institutions where teacher education has been an important activity. Some of the research has been based on design of learning environments but also much of the research has had an ethnographic style, where the learning environments have been investigated 'as they are', without intervention from the researchers.

\subsection{Historical Background}

Didactics of mathematics as an independent scientific discipline can be said to have existed for a little more than 50 years. The late 1960s saw such events as the founding of the journal Educational Studies in Mathematics in 1968 and the first ICME conference in 1969. Almost at the same time, research centres for didactics of mathematics were established in several countries, such as the Institute for the Development of Mathematical Education (later the Freudenthal Institute) in the Netherlands, the Shell Centre in the UK and the Institut für Didaktik der Mathematik in Germany (Gjone, 2013, p. 183). However, it can be claimed that the field of study had already begun to develop in the late 19th century. An important event was the establishing of the first International Commission on the Teaching of Mathematics (ICMI) in 1908 at the Fourth International Congress of Mathematicians in Rome, with Felix Klein as its first president (Kilpatrick, 1992, p. 6). ICMI conducted its first survey in 1912 and, 
according to Kilpatrick, this survey 'reported that university lectures on mathematics education $^{3}$ (to supplement mathematics lectures) were being offered in the United States, Great Britain, Germany and Belgium' (1992, p. 5).

In the history of ICMI, Denmark plays a special role among the Scandinavian countries. Poul Heegaard, who had studied with Klein in Göttingen, was a delegate to the first ICMI in 1908 and also wrote the report from Denmark to be included in the 1912 survey. Heegaard became one of three Vice Presidents of ICMI in 1932. At that time he had left Denmark for a professorship at the University of Oslo, which he held from 1918 until his retirement in 1941 (Furinghetti \& Giacardi, 2012). Later, Svend Bundgaard and Bent Christiansen had important roles in ICMI. Bundgaard was a member of the Executive Committee from 1963 to 1966 and Christiansen served three terms (12 years) as Vice President from 1975. Also, in the years after Christiansen stepped down, the Danish representation in central bodies of ICMI continued to be strong. Mogens Niss became member of the Executive Committee in 1987 and later served as Secretary General for two terms, 1991-1998. Shortly afterwards, a somewhat urgent situation came up in connection with the organising of the 10th ICME conference. It had been assumed that ICME-10 in 2004 should be held in Brazil, but this turned out not to be possible, so an alternative host country had to be found. It was then decided that ICME-10 should be arranged as a collaboration between Denmark, Sweden, Norway, Iceland and Finland. Copenhagen was chosen as the venue, and Mogens Niss became Chair of the International Programme Committee for ICME-10 (Hodgson \& Niss, 2018). Hosting ICME-10 may be seen as the peak of a very long-standing connection between Denmark and ICMI.

In the Scandinavian countries in the early 20 th century there was a rising interest in issues concerning the teaching of mathematics ${ }^{4}$ at school level, including some empirical research. In 1919, K. G. Jonsson obtained his doctoral degree at Uppsala University, Sweden, with a study based on interviews with pupils where he observed and categorised their ways of thinking when solving arithmetic problems (see Johansson, 1986). Bergsten (2002, p. 35) also mentions Karl Petter Nordlund as a pioneer from Sweden. He published his book A Guide for the First Teaching of Arithmetic (Vägledning vid den första undervisningen i räkning) in 1910. The growing interest in educational issues in the early 1900s can be seen in connection with the development of the school system. In the mid-1800s, a state school system for all had been established as a principle in the Scandinavian countries, which led to a need for educating teachers. Teacher education developed in similar ways in all three countries, with a distinction between educating teachers for compulsory school (known as folkeskole in Norwegian and Danish, folkskola in Swedish) and for post-compulsory school (gymnas/ium in Norwegian/Danish, läroverk in Swedish). Institutions educating teachers for compulsory school (Grades 1-7) were referred to as seminaries (seminar/ier in the national languages) and educated general teachers who were expected to teach all school subjects. The system in Sweden differed

\footnotetext{
${ }^{3}$ It is not clear which terms were used to describe these lectures in the various countries and languages.

${ }^{4}$ The term $\operatorname{didaktik}(k)$ was not yet in use in the Scandinavian languages.
} 
somewhat from the system in Norway and Denmark in the sense that in Sweden there were special seminaries educating teachers for Grades 1 and 2. Later, when compulsory school was extended from seven to nine years, Sweden introduced differentiated education for the lower, middle and upper grades (Linné, 2010). In Norway and Denmark, however, the idea of a teacher education covering all of compulsory school was maintained much longer. In Norway, different study programmes for Grade 1-7 teachers and Grade 5-10 teachers ${ }^{5}$ were introduced as late as in 2010.

Initially, becoming a teacher was an option only open to men, but gradually women were also admitted. In Sweden this happened in 1859 (Linné, 2010), with some seminaries exclusively for women then being established. Some of these female teachers played important roles in communicating modern ideas in the teaching and learning of mathematics, ideas that were far ahead of the common ways of thinking at the time. One example is Anna Kruse from Sweden, who published her book Visual mathematics (Åskådningsmatematik) in 1910. This book was meant as a guidebook for other teachers. In the preface to the first edition, she writes that

it is not only a question of giving the child knowledge in a school subject but it is a matter of providing the child a means for acquiring one of the most important factors for the future profession — whatever it may be — clear logical thinking, ability to make judgments, and a practical view. (Kruse, 1910/2010, pp. 29-30, my translation)

It is a fundamental principle in the Scandinavian countries that schooling is part of a democratic endeavour. In the Norwegian context, Telhaug and Mediaas (2003) connect this feature of the school system to the emerging trend in the 19th century that all citizens have a responsibility to take part in the development of the society. These ideas can be traced in didactics of mathematics up to present day through the field of mathematics and democracy, which I will return to later. All three Scandinavian countries were at this time closely connected, as Norway had been part of Denmark for several hundred years until 1814 and then became part of a joint kingdom with Sweden until 1905.

In the first half of the 20th century, compulsory schooling lasted for seven years. A big change in the school system came in the 1950s and early 1960s with an extension from seven to nine years. This also indicated some changes for the subject of mathematics. In the old system, the subject in compulsory school was called regning/räkning (arithmetic), but in the new system the term matematik/k (mathematics) came into use, including in the lower grades. At the same time, also the so-called New Math $^{6}$ started to appear on the international scene, and the ideas from New Math also spread to the Scandinavian countries. A very important event in the introduction of New Math ideas in the mathematics curriculum was the seminar held at Royaumont in France in 1959 (OEEC, 1961). Here, arguments were advanced to let the ideas that had been developed in mathematics as a science over the last 50 years, for instance, through the work of the Bourbaki group, also permeate school mathematics. The outcome of this was, as is well known, a school mathematics with strong emphasis on logic and set theory.

\footnotetext{
${ }^{5}$ Since 1997, Norway has had 10 years of compulsory schooling, starting at the age of six.

${ }^{6}$ Moderne matematikk in Norwegian. Ny matematik in Danish and Swedish.
} 
After the Royaumont seminar, a Nordic committee for the modernisation of mathematics education was established, with four members each from Denmark, Finland, Norway and Sweden. This committee was active from 1960 to 1967. In the recommendations from the committee (Nordisk udredningsserie, 1967) one can find the ideas from the Royaumont seminar expressed in terms of specific topics that were necessary to learn, for instance, set theory. The argument for this is that it will convey to the pupils an understanding for basic concepts. 'Elementary concepts and symbols from set theory make it possible to present the material simpler and clearer'. However, one is also aware of the danger of introducing symbols: 'On the other hand, one has to be careful so that symbols are not experienced as abstract and difficult to understand' (Nordisk udredningsserie, 1967, p. 173, my translation). New Math is often associated with logic and set theory, but it also introduced the concept of function in school mathematics, a concept that has kept its place while many of the formal structures from logic and set theory have been abandoned (Prytz \& Karlberg, 2016).

The ideas of the New Math can be traced back to Felix Klein's Erlanger Programm (Klein, 1872). Through the connection between Felix Klein and Poul Heegaard, Klein's ideas had a strong influence in Denmark in the early 1900s. It seems that the New Math movement became stronger in Denmark and Sweden than in Norway. In Norway, New Math textbooks were used in some schools but they did not dominate the school system to the same extent as in Sweden and Denmark. In the Norwegian National Curriculum from 1974, concepts from set theory and logic are referred to as 'support concepts' (hjelpebegreper) (Kirke- og undervisningsdepartementet, 1974, pp. 143-144). The development in Denmark can, in addition to the early influence by Poul Heegaard, be explained by the work of Svend Bundgaard and Bent Christiansen. Bundgaard, a professor of mathematics at Aarhus University from 1954, was very influential regarding both university mathematics and school mathematics in Denmark. Bent Christiansen had a strong influence on the National Curriculum in Denmark, promoting New Math ideas, and he wrote several textbooks, both for schools and for teacher education. At the upper secondary (gymnasium) level, New Math ideas are clearly expressed in the textbook system Textbookfor the New Upper Secondary School (Larebog for det nye gymnasium) by Erik Kristensen and Ole Rindung that began in 1962. Rindung was also involved in writing the National Curriculum in Denmark (OEEC, 1961; Rønn, 1986). His central position in Denmark is also shown by the fact that he participated at the Royaumont seminar and that he was also a member of the Nordic Committee. Also Erik Kristensen and Bent Christiansen, as well as Agnete Bundgaard, who wrote textbooks for primary school, were members of the Nordic Committee (Nordisk udredningsserie, 1967, p. 220). It is my impression that the members of the Nordic Committee from the other two countries did not to the same extent influence the development of the subject in their respective countries. 


\subsection{Didactics of Mathematics Emerging as a Research Discipline in Scandinavia}

Despite some examples of educational research involving mathematics from the early years of the 20th century, one cannot speak of didactics of mathematics as an independent research discipline in the Scandinavian countries until the 1970s. The early research was done by general educators (pedagogues), using mathematics classrooms as a frame for their empirical studies, and this is still happening. Teachers of mathematics at the teacher training colleges (laererh $\phi$ gskoler/seminarier) were not expected to do research and usually neither did they have the qualifications to do it. At the universities, teacher training (for lower and upper secondary school) involved doing a short add-on after taking a degree based on studies in the subject itself. Each university usually employed at most one person to take care of the actual teacher training part of mathematics teacher education. There were mathematicians at the universities with strong interest and engagement in educational matters, and some of them played important roles in developing teacher education and mathematics as a school subject although they did not do research in didactics of mathematics. The content of the teacher training in the school subjects was mostly focused on technical matters: how to carry out the teaching. The more theoretical parts were dealt with in the subject of pedagogy. In the 1970s there was a turn towards including topics about how learning takes place and such topics as motivation for learning in individual subjects, with the subject of mathematics being quite far ahead in this development. It was also around this time that the expression matematik( $k) \operatorname{didaktik}(k)$ came into use. Earlier, at least in Norway, one had talked about metodikk (methods, i.e., methods for teaching) instead of didaktikk. A book written by Solvang and Mellin-Olsen (1978) for use in teacher education in Norway can serve as an example of the transition from methods to didactics. The title of the book is Mathematics Subject Methods (Matematikk fagmetodikk), which points to the aspect of methods, but the content is wider and more modern in that it also contains learning theories and theories about different rationales for learning mathematics. In Sweden, Christer Bergsten pinpoints the use of the term didaktik to the mid-1980s and claims that the first course with the title matematikdidaktik was given at Linköping University in 1985 (Bergsten, 2002, p. 37). Personally, I remember that when I did my teacher training in 1982, the title of the course was matematikkdidaktikk, and the main literature was the book The Psychology of Learning Mathematics (Skemp, 1971), emphasising constructivist/cognitivist learning theories.

In the early years, the most important institution for research in didactics of mathematics in Denmark, perhaps in Scandinavia as a whole, was Danmarks Lærerhøjskole (The Royal Danish School of Educational Studies), an institution where teachers could get continuing education. The institution later changed its name to Denmark Pedagogical University and is today part of Aarhus University, but still located in Copenhagen. In the 1970s, new universities were established in Denmark: Roskilde University in 1972 and Aalborg University in 1974. These universities were meant to be different from the 'old' Danish universities in Copenhagen and Aarhus, with a 
profile based on problem-based and project-organised work in groups. From around 1980, Roskilde University emerged to become a centre for didactics of mathematics in Denmark, and this university also engaged in educating mathematics teachers with a strong didactical component for upper secondary school, which made it rather exceptional in Denmark. Until recently, Roskilde has probably had the highest activity in didactics of mathematics in Denmark. At Aalborg, didactics of mathematics also developed as a research field, with a strong profile towards socio-political aspects of mathematics education. The result of the activity at Danmarks Lærerhøjskole was that Denmark was far ahead of the other two countries in the early years.

In Norway, teachers at the teacher training colleges (laererh $\phi g s k o l e r)$ gradually started to become acquainted with research literature in didactics of mathematics. Some of them also started doing research, and a few went abroad to get a Ph.D. in didactics of mathematics. Around 1970, a new type of higher education institution was developed in Norway known as regional colleges (distriktshøgskoler), and some of these developed into mini-universities, offering traditional university subjects such as mathematics. This development is somewhat similar to the development in Denmark that resulted in the universities in Roskilde and Aalborg. Some of the regional colleges were established at places where there already was a teacher training college nearby, in some cases even in the same town. In Kristiansand, Kristiansand lærerhøgskole and Agder distriktshøskole coexisted until they merged into Agder University College (Høgskolen i Agder), now University of Agder, in 1994. This merger brought together a strong group of mathematicians and a strong group of teacher educators in mathematics. In the same year as the merger took place, a twoyear master's programme (hovedfag) in didactics of mathematics was established. This developed further into a Ph.D. programme, starting in 2002. In the development that took place at Agder, Trygve Breiteig, one of the senior teacher educators and didacticians in Norway, played a very active role. The programme at Agder is still the only Ph.D. programme in Norway dedicated specifically to didactics of mathematics, although it is possible to do a Ph.D. in the field at other universities, either in a programme based in pedagogy (education) or in mathematics. The Ph.D. programme at Agder led to the appointment of professors from abroad, and this programme has been instrumental in providing Norwegian universities with $\mathrm{Ph} . \mathrm{D}$. graduates in didactics of mathematics. In Norway, all teacher education has recently been made into five-year master's programmes. This puts certain formal requirements on the scientific qualifications of the staff, which has created a situation where the demand is much higher than the supply. The development in teacher education over a number of years has led to a strong increase in the activity in didactics of mathematics in Norway.

Regarding the situation in Sweden, the activity has grown considerably from 1980 onwards. At least 20 dissertations concerning learning of and education in mathematics were defended in the period 1981-1999 (e.g., Strässer, 2005). Most of the dissertations have been submitted within educational sciences but with a focus on mathematics, and among the Swedish universities, the Gothenburg University stands out as being responsible for a large number of the dissertations. 
An important event influencing the situation in Sweden happened in March 2000, when the board of the Bank of Sweden Tercentenary Foundation (Riksbankens Jubileumsfond) offered to support didactics of mathematics in Sweden by setting up a national graduate school in mathematics with a profile towards didactics of mathematics (matematik med ämnesdidaktisk inriktning). This will later be referred to as the Swedish Graduate School. All mathematics and general education departments in Sweden were invited to participate in the graduate school, with 10 departments chosen and 20 students admitted when the activity started in 2001 (Leder, Brandell, \& Grevholm, 2004, p. 170). The Swedish Graduate School had the following effect: In addition to increasing the research activity in didactics of mathematics in Sweden, many departments of mathematics have become more engaged in didactical issues and the activity has spread to more universities and university colleges (högskolor).

The University of Umeå holds a special position when it comes to didactics of mathematics in Sweden. At Umeå, plans for a Ph.D. programme in didactics of mathematics were made in the mid-1990s, before the Swedish Graduate School became a reality. The activity at Umeå and the Swedish Graduate School helped Sweden make a leap forward among the Scandinavian countries regarding research in didactics of mathematics.

After this exposition of the early development, in the next three sections I will go into more detail about the development in each of the three countries. In these sections I will describe some of the areas that have been researched in each of the countries up to the present time.

\subsection{The Development in Denmark}

I have shown that in the beginning Denmark was far ahead of the other Scandinavian countries in establishing didactics of mathematics as a research area, starting at Danmarks Lærerhøjskole and continuing in particular at the universities in Roskilde and Aalborg. Today the situation has to a large extent turned around. In the period from 1988 to 2010, a number of external funding opportunities enabled Danish universities to educate Ph.D. candidates. However, when the funding ended, the activity was greatly reduced and only a few of the Ph.D. candidates were able to find university positions. The development in Sweden resulting from the Ph.D. programme at Umeå and the Swedish Graduate School and in Norway with the Ph.D. programme at Agder seem to have had more lasting value. In addition, teacher education both in Sweden and Norway has become increasingly more research based, contributing to a strong demand for research-qualified staff. In Denmark, teacher education for compulsory school is still to a large extent carried out by people without research qualifications, and the didactical component of teacher education for upper secondary school is rather small. Structural changes among and within the universities have also made didactics of mathematics less visible. Danmarks Lærerhøjskole, which had been an independent university, is now reduced to a department within Aarhus University. At Roskilde, the university has decided to close down both mathematics as an indepen- 
dent subject of study and the teacher education programme. This programme was rather unique in the Danish context as the teachers it educated for upper secondary school were given good backgrounds in didactics of mathematics. In recent years, several senior researchers have retired and not been replaced or have moved to other countries. There are currently some small research groups in didactics of mathematics at the universities and a few active researchers at the university colleges. I have for some years been involved as an external evaluator of proposals for Ph.D. scholarships in Denmark. Based on experiences from the most recent evaluation process, it seems that the recruitment of Ph.D. students in didactics of mathematics is slightly improving. It is also clear that the activity in the field at Copenhagen University is increasing. This I will also return to later. In the following sections I will go into some detail about fields that are and have been of particular importance in Denmark.

\subsubsection{Mathematical Modelling}

From the beginning, the programme in mathematics at Roskilde University was based on ideas from mathematical modelling, with Mogens Niss as the central researcher, followed by Morten Blomhøj. One aspect of how Niss sees mathematical modelling is 'to perform active modelling in given contexts, i.e., mathematising and applying it to situations beyond mathematics itself' (Niss \& Højgaard, 2011, p. 58). Mathematical modelling in the Danish tradition is very much connected to handling problems from real life. This leads to the formulation of a task and further to systematisation, mathematisation, mathematical analysis, interpretation/evaluation and finally to validation by going back to the real-life situation. This is illustrated in the modelling cycle in Fig. 6.1.

Fig. 6.1 The modelling cycle (Blomhøj \& Kjeldsen, 2006, p. 166, with permission)

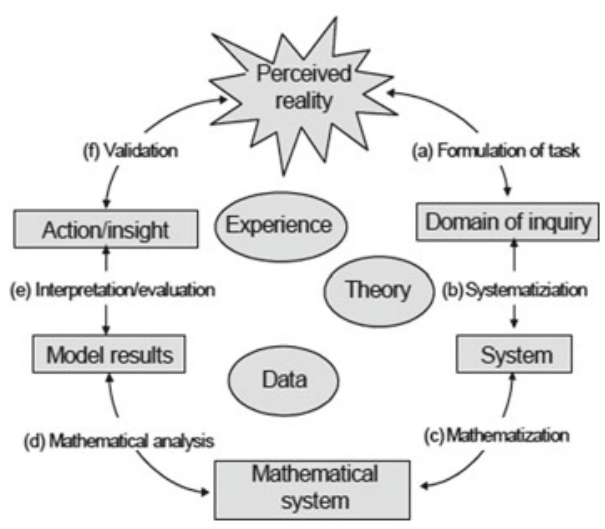


In the literature, mathematical modelling is used with slightly different connotations. Note that the Danish tradition is close to applications of mathematics to real life problems, whereas modelling is used in a wider context, for example, in the Dutch tradition, in the concept of emergent modelling (e.g., Gravemeijer, 2007).

\subsubsection{Mathematical Competencies}

In 2000, the Danish Ministry of Education established a group, led by Mogens Niss, for the project Competencies and Mathematical Learning (Kompetencer og matematiklæring $[\mathrm{KOM}])$. The idea behind the project was to develop an alternative to the traditional idea of thinking about a subject in terms of the syllabus (pensumtenkning) when designing content of and goals for school subjects. Mathematics was chosen as the first subject for the new approach. This work led to the idea of describing certain competencies which, seen together, constitute what may be called mathematical competence. The complete report from the group was published in Danish (Niss \& Jensen, 2002) and later translated into English (Niss \& Højgaard, 2011). The group identified eight competencies, divided into two groups: 1 . The ability to ask and answer questions in and with mathematics and 2 . The ability to handle mathematical language and tools. The first group contains the following four competencies: mathematical-thinking competency, problem-tackling competency, modelling competency and reasoning competency. The second group is composed of representing competency, symbol and formalism competency, communicating competency, and aids and tools competency. The eight competencies are often presented in the 'competency flower' shown in Fig. 6.2.

This work has had great impact on mathematics education, not only in Denmark and the other Scandinavian countries but also more widely, for instance, in Germany (see Blum, Drüke-Noe, Hartung, \& Köller, 2006).

Fig. 6.2 The competency flower (Niss \& Højgaard, 2011, p. 51, with permission)

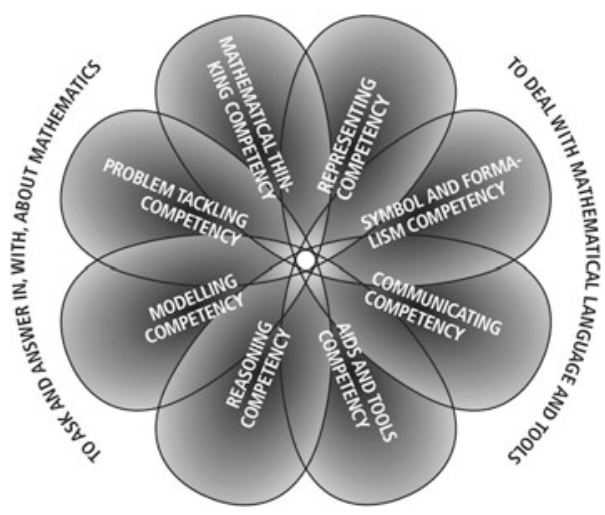




\subsubsection{Political Aspects of Mathematics}

Under this heading I have placed two important trends that have been particularly strong in Denmark. One of these is critical mathematics education, represented by Ole Skovsmose. This trend has also been important in Norway, which I will cover in that section. Skovsmose (2010) describes how in the early 1970s he developed an interest in critical education and then in particular in critical mathematics education. This development was connected to the student movements that swept through Europe from 1968. Out of this evolved a view that university studies should serve not only academic but also political and social interests. The most comprehensive presentation of his ideas can be found in the book Towards a Philosophy of Critical Mathematics Education (Skovsmose, 1994).

Also Skovsmose's concepts of landscape of investigation and exercise paradigm (Skovsmose, 2001) connect to critical mathematics education. Skovsmose contrasts the approach to teaching where the teacher and the textbook are the authorities in the classroom with that of an investigative approach. The former he denotes the exercise paradigm and the latter a landscape of investigation. In the exercise paradigm, the relevance of the matter taught is not questioned, there is one and only one correct answer and it is the role of the student to acquire the knowledge presented by the textbook and the teacher. A landscape of investigation is linked to, for example, project work, which he describes as being "located in a "landscape" which provides resources for making investigations' (Skovsmose, 2001, p. 123). Skovsmose links this idea to critical mathematics education and the term mathemacy, which 'refers not only to mathematical skills, but also to a competence in interpreting and acting in a social and political situation structured by mathematics' (p. 123). In this view, mathematics is not only a subject to be learnt but also a subject to be thought about and reflected upon. Skovsmose takes the stance that there should be room for critical voices in mathematics education and he sees no possibilities for that within the exercise paradigm. In a later publication, Skovsmose (2003) recognises that his concept of the exercise paradigm is very much akin to the concept of exercise discourse (oppgavediskursen) that Stieg Mellin-Olsen had defined based on his empirical work with Norwegian teachers several years earlier (Mellin-Olsen, 1991). Mellin-Olsen describes the role of exercises in mathematics education as structuring the lessons. The exercises have a beginning and an end, and the end is marked by an answer that may be found in a list of solutions (fasit). The exercises follow in a sequence, and when one is finished, the next exercise awaits. The final goal is the exam (Mellin-Olsen, 2009, p. 2). Although there are clear similarities between the work of Mellin-Olsen and the work of Skovsmose, there are also some clear differences in the way they approach critical aspects of mathematics education. While Mellin-Olsen certainly was critical of the ways mathematics was taught in school, it can be said that Skovsmose to a larger extent also expressed critical views towards mathematics itself (Skovsmose, 2002). 
The second trend that I will place under this heading is mathematics and democracy. This goes back to an initiative in the late 1980s that turned out to have important consequences for the whole Nordic area. Gunhild Nissen, a professor of education at Roskilde University, got funding for a five-year project entitled Mathematics Education and Democracy (Matematikundervisning og demokrati). This led to establishing a network of mathematicians, didacticians, teachers and researchers from education and psychology. The work soon led to an extension of the network outside of Denmark to include the other Nordic countries, and the first Nordic symposium on research in didactics of mathematics was held in Gilleleje, Denmark, in 1990. The project was founded on a humanistic-democratic approach to mathematics and, given the similarities between the Nordic countries, it was believed that there could be a common platform for collaboration. A central idea in the project was a desire to change the common perception of mathematics as a formalistic subject and to challenge the view that, besides basic arithmetic, people at large did not need to obtain substantial knowledge of mathematics. Nissen claims that with the more widespread use of mathematics, not only as a basis for technology, natural sciences and economy but also for administrative systems and models forming the basis for political decisions, it is necessary that everybody can take a well-informed and critical stance to the use of mathematics in order to be able to participate in a democratic society (Nissen, 1994, pp. 58-59). The project was later recognised as a Nordic project under the auspices of the Nordic Academy for Advanced Study (Nordisk Forskeruddannelsesakademi), and funding became available to provide scholarships for Ph.D. students (Nissen, 1993). One of the lasting outcomes of the work on the project is the journal Nordic Studies in Mathematics Education (NOMAD). The Mathematics Education and Democracy project gave financial support for the planning meetings for NOMAD, which came out with its first issue in October 1993 (Johansson, 1993). For more about NOMAD, see Sect. 6.7 of this chapter.

\subsubsection{The French Tradition in Denmark}

In the early years, there was not much activity in didactics of mathematics at Copenhagen University. However, this has changed in recent years. Now there is an active research group around Carl Winsløw. His research is to a large extent directed to research on the teaching and learning of mathematics in higher education (e.g., Gravesen, Grønbæk, \& Winsløw, 2017). Theoretically, Winsløw maintains a strong connection to the French tradition, the Theory of Didactical Situations, commonly known as TDS (Brousseau, 1997) and the Anthropological Theory of the Didactic, commonly known as ATD (e.g., Bosch \& Gascón, 2014). These theoretical approaches have traditionally not been well known in the Scandinavian tradition, but the work of Winsl øw has contributed to a more widespread knowledge about them and also led to them being used by other Scandinavian researchers (e.g., Måsøval, 2011). 


\subsection{The Development in Norway}

When didactics of mathematics as a scientific discipline started to emerge in Norway, the whole community of didacticians was very small, comprising around 20-25 persons in the whole country, mostly confined to teacher training colleges (larerhøgskoler). Until around 1990, mathematics at teacher training colleges was a very small subject. Typically, each college would employ one or two mathematics teachers, without research qualifications or research possibilities. It is questionable whether all of these could be referred to as didacticians, but they certainly taught mathematics to prospective teachers. There was also some activity at the universities, in particular at the universities in Oslo and Bergen. Gunnar Gjone at the University of Oslo wrote a Ph.D. thesis on the New Math movement in 1983 and later worked on curriculum development and the use of ICT in mathematics, among other things. I will limit my detailed description of the early research to two persons, Gard Brekke and Stieg Mellin-Olsen. I have made this choice because these two had a strong influence on the development of didactics of mathematics in Norway and because they represent two different theoretical traditions: a constructivist tradition and a socio-cultural tradition.

\subsubsection{The Constructivist Tradition}

Gard Brekke (1943-2009) obtained his Ph.D. from the University of Nottingham at the Shell Centre for Mathematical Education in 1991. He played a very important role in didactics of mathematics in Norway for several decades, both as a researcher, a teacher educator (at Telemark University College) and by taking on tasks for the national authorities. Brekke, together with Gunnar Gjone, took the initiative to create the Quality in Mathematics Education (Kvalitet i matematikkundervisningen [KIM]) project in the early 1990s. This project, funded by the Norwegian Ministry of Education, aimed at developing a library of diagnostic tasks in mathematics that covered most areas of mathematics in all of compulsory school and parts of upper secondary school. The project also aimed to survey beliefs and attitudes about mathematics held by pupils in school (Brekke, 1994). The diagnostic material was intended to be used by teachers, and Brekke wrote a leaflet meant to serve as a guide to teachers for how to use the material (Brekke, 2002). Here Brekke gives his contribution to characterising knowledge in mathematics by asking the question 'what does it mean to know mathematics?' Brekke's answer to this is that mathematical competency consists of five components:

1. Factual knowledge, e.g., definitions, notation and conventions.

2. Skills, defined as well-established procedures, such as knowing how to compute the product of multi-digit numbers.

3. Conceptual structures, exemplified by multiplicative structures. 
4. General strategies, defined as the ability to choose suitable skills to solve a problem from an unknown situation.

5. Attitudes. (Brekke, 2002, pp. 4-9, my translation)

The fifth component is motivated by Brekke (2002) by saying that 'our view (both as a teacher and as a pupil) on mathematics, will decide how the teacher teaches the subject, and how the pupil meets the subject matter' (p. 9, my translation). Brekke's framework for mathematical competence precedes the competency framework developed by Mogens Niss (Niss \& Jensen, 2002), but it is not as detailed as this. One important difference is that unlike Niss, Brekke includes an affective component. In this sense, Brekke is in line with the framework by Kilpatrick, who includes productive disposition as one of five strands (Kilpatrick, Swafford, \& Findell, 2001, p. 116).

Diagnostic teaching is based in the constructivist/cognitivist tradition and a central concept of this is the concept of a cognitive conflict. To create such a conflict, it is necessary to design tasks in particular ways so that they can uncover misconceptions. The tasks developed for the KIM project were inspired by a tradition that was very strong in the UK from the 1970s onwards. Much work on diagnostic teaching was done, in particular at the Shell Centre in Nottingham (e.g., Bell, 1993). Since Gard Brekke spent several years at the Shell Centre in the late 1980s and obtained his Ph.D. there in 1991, it is natural that this tradition influenced his work. Given Brekke's central position in the Norwegian community of teacher educators, it is also natural that it influenced didactics of mathematics in Norway more widely.

\subsubsection{The Socio-cultural Tradition}

A different theoretical tradition in Norway can be identified when going into the work of Stieg Mellin-Olsen (1939-1995) at the University of Bergen. In 1977 he had already published his book Learning as a Social Process (Laring som sosial prosess; Mellin-Olsen, 1977). In the first chapter of this book, Mellin-Olsen discusses Piaget's theory of knowledge. This discussion develops into a critique of Piaget, but first he extracts what he sees as the main point in Piaget's theory: '[K]nowledge is connected to work. It is the way we work that decides what kind of knowledge we develop' (Mellin-Olsen, 1977, p. 18, my translation, emphasis in original). From this he develops his concepts causal (or relational) understanding (årsaksforståelse) and instrumental understanding (instrumentell forståelse) and links these concepts to Piaget's concepts of operational and figurative knowledge (p. 20). The concepts relational understanding and instrumental understanding are usually attributed to Richard R. Skemp and are widely known from his paper with the same title (Skemp, 1976). However, Skemp and Mellin-Olsen collaborated in the 1970s, and they refer to each other's work when they write about different forms of understanding. Thus far, one may say that Mellin-Olsen is aligned with constructivism, but later in his book he presents a critique of Piaget (Mellin-Olsen, 1977). This critique is rooted 
in an experiment that Mellin-Olsen was involved in at a lower secondary school in Bergen that was set up with a test group using an alternative curriculum and a control group using the traditional curriculum. The experiment lasted for two years and, probably to the researchers' disappointment, the result was that the test group did not do any better than the control group. However, Mellin-Olsen and his colleagues realised that when evaluating educational experiments, the traditional psychological variables are insufficient to explain the outcome. Mellin-Olsen (1977) writes that it turned out to be necessary to also take into account anthropological and sociological considerations, such as pupils' thoughts about the school and what they expect from it (p. 22).

Mellin-Olsen brought ideas into the field of didactics of mathematics that presented an alternative to the constructivist/cognitivist tradition that was prevailing at the time. In his book published in 1987 he makes clear references to Vygotsky and his successors and he devotes the first chapter of this book to activity theory (MellinOlsen, 1987). However, in Learning as a Social Process (Mellin-Olsen, 1977) there are no references to Vygotsky. When writing the 1977 book he may not even have been familiar with Vygotsky's theories. At that time, Vygotsky's writings were not easily available outside of the Soviet Union and, if at all, only in Russian. Although the first English version, not quite complete, of Thought and Language came out in 1962, it was not until the late 1970s that more of Vygotsky's work became available (Kozulin, 1985, pp. liv-lvi). In his 1987 book, Mellin-Olsen writes that 'still only two modest books by Vygotsky are available in English' (p. 29), and in this book (e.g., p. 20) he elaborates on his critique of Piaget. Mellin-Olsen is clearly concerned with the school's and the subject of mathematics' role as reproducers of social injustice, and in this sense he can be seen as a public educator: in the terms of Ernest (2000), as one whose mathematical aims are '[e]mpowerment of learners as critical and mathematically literate citizens in society' (p. 6).

\subsubsection{Further Work Within the Socio-cultural Paradigm}

In the more recent activity in Norway one can also see that socio-cultural theories play an important role. At the University of Agder, much of the activity is generated from a socio-cultural standpoint. This can be seen for example in the work on inquirybased learning initiated by Barbara Jaworski (e.g., Jaworski, 2006). Socio-cultural traditions are also visible in the research using activity theory (e.g., Jaworski \& Goodchild, 2006). Also contributing to the socio-cultural tradition at Agder was Maria Luiza Cestari. She collaborated closely with Roger Säljö from Gothenburg, who held a visiting professorship at Agder for some years.

In Bergen, the tradition of Stieg Mellin-Olsen has mainly been continued at the teacher education part of what now is Western Norway University College. For many years, Marit Johnsen-Høines was the leading person at this institution. She is now retired and the group is now led by Tamsin Meaney. She has an international reputation as a researcher on multicultural and multilingual mathematics classrooms. 
Since she took up the position in Bergen, this is now one of the research areas of the group, in addition to critical perspectives on mathematics education and mathematics for young children.

At the University of Troms $\emptyset$, the northernmost university in Norway, there is a research group with a particular interest in mathematics related to the Sami culture in Norway. Anne Birgitte Fyhn has led or has been involved in several research projects with connection to the Sami culture (e.g., Fyhn, 2010). In this respect, there are similarities between the activity in Troms $\varnothing$ and Bergen, and these similarities have also led to collaboration between the two groups (e.g., Fyhn, Meaney, Nystad, \& Nutti, 2017).

\subsubsection{Research on University Didactics}

Research in didactics of mathematics at higher education is a rapidly growing field internationally. This is noticeable through the increasing number of publications in the area, with new journals appearing, and also through centres in various countries focusing on university mathematics. This area has also gained ground in Norway, to a large extent due to the Centre for Excellence in Education, Centre for Research, Innovation and Coordination of Mathematics Teaching (MatRIC), ${ }^{7}$ hosted by the University of Agder. MatRIC was established in 2014 and aims to support developmental projects for mathematics at higher education but also to do research through staff and Ph.D. students. There is also some activity on research on mathematics at higher education at the Norwegian University of Science and Technology (NTNU), mainly connected to projects for reforming the basic courses in mathematics and statistics for engineering students (e.g., Rønning, 2017).

\subsubsection{Classroom Research and Research on Aspects of Teacher Education}

In addition to the University of Agder, the University of Stavanger is another of the 'new' universities (former university colleges) in Norway that has developed a strong group of researchers in didactics of mathematics. The activity at Stavanger has been dominated by work on mathematical knowledge for teaching (MKT), as developed by Deborah Ball and colleagues (e.g., Ball, Thames, \& Phelps, 2008). The group at Stavanger has worked on translating the MKT test items from English to Norwegian and testing them out on Norwegian teachers (e.g., Fauskanger, 2015). Another area that has attracted interest at Stavanger is lesson study. Raymond Bjuland was the leader of an interdisciplinary project, Teachers as Students, where lesson study as

\footnotetext{
${ }^{7}$ www.matric.no.
} 
a method was tried out in several subjects, including mathematics (e.g., Munthe, Bjuland, \& Helgevold, 2016).

NTNU, which after a recent merger now is the largest university in Norway, includes a large Department of Teacher Education with some 25-30 persons working mainly with mathematics in teacher education for compulsory school. The majority of this group came to NTNU from Sør-Trøndelag University College through the merger. Many of these people are young, often with a Ph.D. in mathematics, and are in a developing phase as researchers in didactics of mathematics. The group at the Department of Teacher Education has a close connection to the small group at the Department of Mathematical Sciences, for instance, through the collaborative project Language Development in the Mathematics Classroom. This is a project where researchers and teachers at two primary schools work together over several years to study the importance of the learning environment for young learners' development of mathematical thinking and understanding (e.g., Dahl, Klemp, \& Nilssen, 2017; Rønning \& Strømskag, 2017). There is also on-going research regarding various aspects of pre-service teachers' development into the teaching profession (e.g., Enge \& Valenta, 2015).

\subsubsection{Large-Scale Studies}

Much of the research in Norway is of a qualitative character. However, Norway has actively participated in the TIMSS and PISA studies, and this activity is confined to the University of Oslo, where the research group in didactics of mathematics has been responsible for the national reports from these studies (e.g., Bergem, Kaarstein, \& Nilsen, 2016; Kjærnsli \& Jensen, 2016).

\subsection{The Development in Sweden}

Presently, Sweden is the Scandinavian country with the by far largest activity in didactics of mathematics and with the largest number of researchers in the field. Several of the candidates from the Swedish Graduate School (see Leder et al., 2004) now hold professorships at various universities in Sweden. Not only is the level of activity high but the activity is also very diverse, so it will not be possible to cover all areas in this chapter. I will start by presenting in some depth two of the 'old' areas and then proceed to some of the more current activity. The presentation of the current situation is strongly based on information that has been sent to me upon request from colleagues in Sweden. 


\subsubsection{Low Achievement}

It seems natural in a presentation of Swedish work on didactics of mathematics to start with the work on low achievement. In this area, Olof Magne was a pioneer (Magne, 1958). Typical for Magne's studies is that they cover a large number of pupils and/or are followed up over several years. His study in 1953 covered all 6000 pupils in three random school districts of the compulsory school system in Gothenburg (Engström \& Magne, 2010, pp. 335-336). In the late 1970s, Magne initiated the large project known as the Middletown Mathematics Project (Medelsta-matematik). Middletown, a fictitious name for a municipality of 25,000 inhabitants, was selected to represent an average municipality in Sweden. Its compulsory school (grundskola) had about 2000 pupils. In 1977, all pupils at the school from Grades 1 to 9 were tested using assessment material developed as part of the project. The Middletown study was repeated in 1986 and again in 2002 (see Engström \& Magne, 2010 for more details).

\subsubsection{Phenomenography and Variation Theory}

In a paper from 1981, Ference Marton, at the Department of Education at the University of Gothenburg, presented a new approach to research which he denoted phenomenography. In this paper he makes a distinction between making statements about the world and making statements about people's ideas about, or experiences of, the world (Marton, 1981, p. 178). Initially, this research did not have anything in particular to do with mathematics. However, it turned out that it would be used in a number of research projects where mathematics played an important role. The successful application of variation theory to the study of teaching and learning of mathematics may explain the important and perhaps even dominating role of the Department of Education at Gothenburg at a rather early stage of didactical research.

After a large number of empirical studies using the phenomenographic approach, there emerged a more theoretical approach known as variation theory. Runesson and Kullberg (2010) denote this as the theoretical turn of phenomenography. The main idea here is that 'learning takes place, knowledge is born, by a change in something in the world as experienced by a person' (Marton \& Booth, 1997, p. 139). A basic principle for variation theory is that if something varies and something else remains constant, it is more likely that the thing that varies will be noticed, and further it is assumed that the phenomenon that is noticed is more likely to be learned. In collaboration with researchers from Hong Kong, an approach known as learning study was developed (Runesson \& Kullberg, 2010). This can be described as an intervention model where teachers and researchers work together designing lessons on a specific topic with specific learning goals. 


\subsubsection{Learning by Imitative and Creative Reasoning}

Johan Lithner at Umeå University has developed a framework for reasoning. He argues that although there are several frameworks for describing, for example, stages of understanding (such as Hiebert \& Lefevre, 1986; Sfard, 1991; Skemp, 1976), 'there are not many that aim at characterising the reasoning itself' (Lithner, 2008, pp. 255-256). In his work he has used several terms to characterise different types of reasoning, for instance, plausible reasoning and reasoning based on established experiences (Lithner, 2000). Later, he turns to the main categories, creative reasoning and imitative reasoning, with imitative reasoning split into the subcategories of memorised reasoning and algorithmic reasoning (Lithner, 2008). A main point was to characterise the key aspects of imitative reasoning, which was found to be the dominating type of reasoning in the empirical data. The framework of creative and imitative reasoning has also been used in a number of other studies and by other authors, both within and outside of the Nordic community. Another example from Umeå is by Ewa Bergqvist who studied the type of reasoning required to solve exam problems (Bergqvist, 2007). A synthesis of the research outcomes in this area can be found in Lithner (2017).

\subsubsection{Assessment}

There is work on assessment taking place at many universities in Sweden. At Umeå University, formative assessment is an important field, and the work there is closely connected to classroom practice and the results are meant to be used both by practitioners and as a background for educational research and school development projects, in collaboration between the university, schools and municipalities (e.g., Andersson \& Palm, 2017a, b).

At Stockholm University, there is a research group known as the PRIM Group, which is focusing in particular on various aspects of assessment. The PRIM Group has a national responsibility for developing tests and various types of assessment material for use in Swedish schools, and it is also responsible for the Swedish part of the PISA project. The PRIM Group is led by Astrid Pettersson and has more than 20 people working with particular tasks, from designing tests to performing statistical analyses of results (e.g., Pettersson \& Boistrup, 2010).

\subsubsection{Mathematics and Language}

Mathematics and language is a research area with high international activity, such as with topic groups at CERME and ICME. This area is also represented in Swedish research. The overarching purpose of the research in this area is to increase 
the understanding of the role language and communication has for knowledge and learning in mathematics by studying, for example, connections between types of argumentation and students' understanding of mathematical explanations. At Umeå University, Magnus Österholm, Ewa Bergqvist and Anneli Dyrvold are working in this field (e.g., Dyrvold, Bergqvist, \& Österholm, 2015; Österholm \& Bergqvist, 2013). Also at Uppsala University there is a research group working on mathematics and language, specialising on text analysis using linguistic methods and collaborating with researchers in linguistics (e.g., Bergvall, Folkeryd, \& Liberg, 2016).

\subsubsection{Early Learning of Mathematics}

At Stockholm University there is a project entitled The Acquisition of Year One Students' Foundational Number Sense in Sweden and England (FoNS, i.e., foundational number sense). This is a comparative study between Sweden and England with the aim of investigating how teachers and parents in Sweden and England support year one students to learn the skills defined as FoNS. Furthermore, it is also the aim of the project to help teachers and parents in their work supporting children's learning of FoNS. The project is built on the idea that children with poorly developed number sense are likely to remain low achievers throughout their schooling. The project is led by Paul Andrews and several researchers at the department contribute to the project (e.g., Sayers, Andrews, \& Boistrup, 2016).

At other universities there have also been researchers working with early learning, in school and pre-school, such as Maria Johansson at Luleå who has also collaborated with researchers from Malmö University (e.g., Johansson, Lange, Meaney, Riesbeck, \& Wernberg, 2014). Lovisa Sumpter at Stockholm University has also worked with pre-school children (e.g., Sumpter \& Hedefalk, 2015). Another example is Jorryt van Bommel at Karlstad and Hanna Palmér at Linnaeus University who have been working with young children's exploration of probability (Van Bommel \& Palmér, 2016).

\subsubsection{Inclusive Mathematics Education}

I have chosen this heading to cover a variety of activities, including research on political issues in mathematics education, multilingualism and gender issues. I have previously presented critical mathematics education as an area represented by Ole Skovsmose in Denmark and Stieg Mellin-Olsen in Norway. Paola Valero continued the tradition of Skovsmose at Aalborg University in Denmark, but she is currently working at Stockholm University. Valero's current research can be described as exploring the significance of mathematics education as a field where power rela- 
tions are actualized in producing subjectivities and generating inclusion/exclusion of different types of students. In Valero (2017) she shows an example of her recent work.

Under this heading I will also put the work of Eva Norén, also at Stockholm University. One of her main interests has been multilingual students' opportunities to position themselves within discourses. In one paper, she studied a Grade 1 multilingual classroom to explore how students' agency is expressed in the classroom (Norén, 2015a). She has also investigated the positioning of girls and boys in mathematics classrooms (Norén, 2015b). The theoretical basis of Norén's work is Foucault's theory of discourse.

Some of the work of Lisa Björklund Boistrup (Stockholm) could also be placed under the heading of inclusive mathematics education. In her Ph.D. thesis (Boistrup, 2010), she draws on Focault's theory on discourses but her study is also based in social semiotics. I find her work to have clear aspects of inclusion, as she states that she addresses how assessment systems and processes act to benefit or disadvantage individuals or groups (2010, p. 38).

\subsubsection{Research on Particular Mathematical Topics}

Bergsten (2010) has made a list of research topics in Sweden, and in this list there is nothing about research on particular mathematical topics. This situation has changed since 2010. Now there are several research groups working on particular mathematical topic areas, such as algebra. At Uppsala University there is an ongoing project with the title Towards research-based teaching of algebra, which addresses various aspects of school algebra through interviews with teachers and examination of textbooks (e.g., Bråting, Hemmi, Madej, \& Röj-Lindberg, 2016). This project also has a strand on historical methods, which is a speciality of the Uppsala group (e.g., Prytz, 2018). The topic of algebra has attracted much attention in Sweden over the last 15 years or so, partly due to Swedish students' poor performance on tests such as PISA.

As mentioned earlier, there has been a long tradition of doing research in didactics of mathematics at the Faculty of Education at Gothenburg University. This research now also includes research on algebra. There is a project called VIDEOMAT, which is a comparative study involving Sweden, Norway, Finland and the US. This project is based on classroom studies and interviews with teachers and has a particular focus on early algebra and use of variables (e.g., Rystedt, Kilhamn, \& Helenius, 2016).

Much of the activity in the Swedish Graduate School, established in 2000, was linked to departments of mathematics, and with mathematicians taking supervision responsibility. It is reasonable to believe that this led to an increased interest in research on specific mathematical topics. An example of a thesis coming out of the Graduate School, focusing on a specific mathematical topic, in this case the concept of function, is the work by Juter (2006) at Kristianstad University. She has continued to be interested in the concept of function and related topics (e.g., Juter, 2017). 


\subsubsection{Research on Teacher Education}

Many of the researchers in didactics of mathematics in Sweden work at universities where teacher education is an important part of the activity. Therefore, it is also natural that this is an important area of research. One example of research on teacher education is the work done by Jeppe Skott and colleagues at Linnaeus University. Skott is Danish and worked for many years at the former Danmarks Lærerhøjskole before taking up a position at Linnaeus University in Växjö. His research on and with teachers is done under the heading The Makings of a Mathematics Teacher. This is basically about professional identities of teachers in pre-school and compulsory school. The work adopts a social perspective on learning and identity and has led to development of a framework called Patterns of Participation (e.g., Palmér, 2013; Skott, 2013, 2017).

There is also research on teacher education at Karlstad University, in particular connected to professional development of teachers. Various approaches are taken, such as focusing on pupils with special needs and developmental projects involving digitalisation, such as using social media (Van Bommel \& Liljekvist, 2016). Preservice teachers' development is also studied in a project at Kristianstad University by Kristina Juter and Catarina Wästerlid. Groups of pre-service teachers for schoolyears 4-6 are participating in a longitudinal study about identity development in becoming mathematics teachers. Kicki Skog at Stockholm University, taking a sociopolitical theoretical perspective, studies how different cultures, contexts and politics affect what is learnt, how it is learnt and what it is to become a mathematics teacher (Skog, 2014).

\subsection{Important Initiatives Across the Countries}

There is a long tradition of collaboration between the Scandinavian countries, and indeed between all Nordic countries. In more recent years this collaboration has also come to include the Baltic states, most notably Estonia. In this section I will briefly give an account of some of the most important arenas for collaboration in the region.

\subsubsection{Nordic Studies in Mathematics Education (NOMAD)}

Parallel to the development of didactics of mathematics as a research domain, a need grew for an outlet to publish results from research and developmental work. The first initiatives in this direction came with the establishing of journals for mathematics teachers and teacher educators: Matematik in Denmark in 1973, Nämnaren in Sweden in 1974, and Tangenten in Norway in 1990. Along with the development of these professional journals, the idea grew to also have a scientific journal for the Nordic 
region. Mellin-Olsen (1993) reports on an initiative by Göran Emanuelsson (editor of Nämnaren) in 1988 that resulted in a meeting in April 1989 where a group consisting of Gunnar Gjone and Stieg Mellin-Olsen from Norway and Göran Emanuelsson and Bengt Johansson from Sweden was established to work on the idea of creating a new journal. As a result of this work came the journal Nordic Studies in Mathematics Education (NOMAD). The first issue appeared in October 1993. As described in Sect. 6.4.3, the Mathematics Education and Democracy project was important for bringing NOMAD into being as it provided financial support for the planning meetings.

It was decided that articles in NOMAD could be written in Danish, Norwegian, Swedish or English. In the beginning, most articles were written in a Scandinavian language, but, as Bengt Johansson writes in the first issue: 'The aim is that the last issue in each volume should be in English' (Johansson, 1993, p. 6, my translation). It turned out that English soon became the preferred language for publication although there have always been articles in the Scandinavian languages. In the first two full volumes (1994 and 1995), 8 out of 21 articles are in a Scandinavian language, and in the last two volumes (2016 and 2017) only 3 out of 43 articles are in a Scandinavian language. These figures also say something about the growth of the activity in didactics of mathematics research in the Nordic area. The number of published articles per volume in NOMAD has roughly doubled since the early years. In addition to the general increase in didactical research, the increased publishing activity in NOMAD is largely due to the increasing number of Ph.D. candidates, in particular in Sweden and Norway. Each volume of NOMAD consists of four issues and for a number of years now the last issue of each volume has been a thematic issue, related to one particular topic of research. A recent thematic issue (No. 4, 2017) is on university mathematics, reflecting also the growing interest in this particular field.

From the beginning, the responsibility for editing NOMAD shifted between the Nordic countries. The first four volumes were edited in Sweden, with the editorship then shifting to Norway and later to Finland and Denmark. With the growth of electronic communication, the need for having the editors in one place diminished. The country-specific editorship started to break up in 2009 when Johan Häggström joined the Danish editors Morten Blomhøj and Paola Valero, and it continued in 2010 when I replaced Paola Valero in the team. I served on the team of editors from 2010 to 2017. Johan Häggström had been managing editor since 2004, when the National Center for Mathematics Education (NCM) in Gothenburg took over the responsibility for publishing NOMAD. In 2012 the group of editors was extended to five to meet the increasing inflow of papers, with Kristina Juter (Sweden), Markku Hannula (Finland) and Uffe T. Jankvist (Denmark) joining the team. The current editorial team consists of Ewa Bergqvist (Sweden), Janne Fauskanger (Norway), Markus Hähkiöniemi (Finland), Tomas Højgaard (Denmark) and Johan Häggström at NCM, who is also one of two managing editors. 


\subsubsection{The NORMA Conferences}

Around the same time that NOMAD was established came the idea to organise a Nordic conference in mathematics education. Winsløw (2009, p. 1) attributes the idea of a Nordic conference mainly to Erkki Pehkonen from Finland, and the First Nordic Conference on Mathematics Education (NORMA 94) was held in Lahti, Finland, in 1994. This first conference attracted many researchers from Finland and the Baltic states but not as many from the Scandinavian countries. Going through the proceedings (Pehkonen, 1995), I can identify three papers from Sweden, two from Norway and one from Denmark. The NORMA conferences have been held regularly since, with participants both from inside and outside of the Nordic region. In particular, it has been an aim to invite plenary speakers from outside of the Nordic region in addition to speakers from within the region. In Table $6.3 \mathrm{I}$ have listed the NORMA conferences held so far and the names of the plenary speakers at each conference who at the time of the conference were not affiliated with a Nordic university.

Table 6.3 List of NORMA conferences

\begin{tabular}{l|l|l|l}
\hline Year & City & Country & Plenary speakers \\
\hline 1994 & Lahti & Finland & $\begin{array}{l}\text { Joop van Dormolen (NL) } \\
\text { Barbara Jaworski (UK) } \\
\text { Thomas J. Cooney (USA) }\end{array}$ \\
\hline 1998 & Kristiansand & Norway & $\begin{array}{l}\text { Konrad Krainer (A) } \\
\text { Marja van den Heuvel-Panhuizen (NL) } \\
\text { Michal Yerushalmy (IL) }\end{array}$ \\
\hline 2001 & Kristianstad & Sweden & $\begin{array}{l}\text { Maria Alessandra Mariotti (I) } \\
\text { John Mason (UK) } \\
\text { Heinz Steinbring (D) }\end{array}$ \\
\hline 2008 & Copenhagen & Denmark & $\begin{array}{l}\text { Simon Goodchild (UK) } \\
\text { Birgit Pepin (UK) }\end{array}$ \\
\hline 2011 & Reykjavik & Iceland & $\begin{array}{l}\text { Núria Planas (E) } \\
\text { Bharath Sriraman (USA) (F) }\end{array}$ \\
\hline 2014 & Turku & Finland & Helen M. Doerr (USA) \\
\hline 2017 & Stockholm & Sweden & Wim Van Dooren (B) \\
\hline
\end{tabular}




\subsubsection{The Nordic Graduate School for Mathematics Education (NoGSME)}

Based on a grant from the Nordic Academy for Advanced Study, a Nordic Graduate School in Mathematics Education was established for the period 2004-2008 with Barbro Grevholm at Agder University College (now University of Agder) as chair. This came to be known as NoGSME. NoGSME played an important role in developing didactics of mathematics as a research area in the Nordic countries. From the start, about 45 supervisors and 80 doctoral students were connected to NoGSME (Grevholm, 2005, p. 61). An important activity in NoGSME was to arrange summer or winter schools for $\mathrm{Ph} . \mathrm{D}$. students, with a range of invited international experts. In addition, NoGSME supported doctoral courses held at specific universities. Formalised education of researchers in didactics of mathematics was still in an early phase in the region and there was a need for developing supervisor competence. NoGSME recognised this need and organised a range of seminars for supervisors with invited international experts. NoGSME kept close contact with NOMAD and the NORMA conferences. The chair of NoGSME reported extensively on the activity in every issue of NOMAD, and at NORMA 05 in Trondheim a special NoGSME session was held. Editors of NOMAD also participated at NoGSME seminars to offer help in writing papers for a research journal.

In one of her reports in NOMAD Grevholm (2007) starts to discuss what she refers to as the life after NoGSME. This discussion is based on comments from the evaluation panel that conducted the mid-term evaluation of NoGSME. The main concern of the evaluation panel was how to maintain the activity for doctoral students when the funding for NoGSME ended. A need for an organisation that could take responsibility for securing funding for events such as summer schools and also take responsibility for the continuation of the NORMA conferences was identified. This led to the founding of The Nordic Society for Research in Mathematics Education (NoRME) $)^{8}$ in 2008 during the NORMA conference in Copenhagen (see Grevholm, 2008), with the author as the first chair. NoRME is an umbrella organisation where the national associations for mathematics education research in the Nordic and Baltic states and NOMAD are the members. As could be expected, it was not possible to maintain the high activity level from NoGSME after the funding ended. However, a few summer schools have been arranged under the auspices of NoRME. In addition, NOMAD has arranged a seminar for Ph.D. students every year since 2012. NoRME is recognised as an international organisation in mathematics education and is given an account in Hodgson, Rogers, Lerman, and Lim-Teo (2013). The present chair of NoRME is Eva Norén at Stockholm University.

Acknowledgements I am extremely grateful to a number of people for having provided information that made it possible for me to write this chapter. I owe big thanks to the following colleagues from Sweden for supplying valuable information: Paul Andrews, Lisa Björklund Boistrup, Jorryt van Bommel, Bengt Johansson, Kristina Juter, Ulla Runesson Kempe, Cecilia Kilhamn, Hanna Palmér,

${ }^{8}$ www.norme.me. 
Johan Prytz, Andreas Ryve, Jeppe Skott, Timo Tossavainen, Paola Valero and in particular Johan Lithner who has also read and commented on an early version of the manuscript. Above all I want to thank Mogens Niss, who has provided much of the information about Denmark and about the early history in general. I also thank him for valuable discussions and for having read and commented on several versions of the manuscript. I emphasise that the selection of material and the way the material is presented is entirely my own responsibility.

\section{References}

Andersson, C., \& Palm, T. (2017a). Characteristics of improved formative assessment practice. Education Inquiry, 8(2), 104-122.

Andersson, C., \& Palm, T. (2017b). The impact of formative assessment on student achievement: A study of the effects of changes to classroom practice after a comprehensive professional development programme. Learning and Instruction, 49, 92-102.

Ball, D. L., Thames, M. H., \& Phelps, G. (2008). Content knowledge for teaching. What makes it special? Journal of Teacher Education, 59(5), 389-407.

Bell, A. (1993). Some experiments in diagnostic teaching. Educational Studies in Mathematics, 24, 115-137.

Bergem, O. K., Kaarstein, H., \& Nilsen, T. (Eds.). (2016). Vi kan lykkes i realfag. Resultater og analyse fra TIMSS 2015 [We can succeed in mathematics and science. Results and analysis from TIMSS 2015]. Oslo: Universitetsforlaget.

Bergqvist, E. (2007). Types of reasoning required in university exams in mathematics. Journal of Mathematical Behavior, 26, 348-370.

Bergsten, C. (2002). Faces of Swedish research in mathematics education. In C. Bergsten, B. Grevholm, \& G. Dahland (Eds.), Action and research in the mathematics classroom. Proceedings of MADIF2, Göteborg, 26-27 January 2000 (pp. 21-36). Linköping: SMDF.

Bergsten, C. (2010). Mathematics education research in Sweden: An introduction. In B. Sriraman, et al. (Eds.), The first sourcebook on Nordic research in mathematics education (pp. 269-282). Charlotte, NC: Information Age Publishing.

Bergvall, I., Folkeryd, J. W., \& Liberg, C. (2016). Linguistic features and their function in different mathematical content areas in TIMSS 2011. Nordic Studies in Mathematics Education, 21(2), $45-68$

Björkqvist, O. (2003a). A sampler of research problems in Nordic mathematics education research. In A. Tengstrand (Ed.), Proceedings of the Nordic Pre-conference to ICME10, 2004 (pp. 13-21). Gothenburg: National Center for Mathematics Education.

Björkqvist, O. (2003b). Matematikdidaktiken i Sverige - en lägesbeskrivning av forskningen och utvecklingsarbetet [Didactics of mathematics in Sweden-A description of the state regarding research and development]. Stockholm: Kungliga Vetenskapsakademin.

Blomhøj, M., \& Kjeldsen, T. H. (2006). Teaching mathematical modelling through project workExperiences from an in-service course for upper secondary teachers. ZDM-Mathematics Education, 38(2), 163-177.

Blum, W., Drüke-Noe, C., Hartung, R., \& Köller, O. (Eds.). (2006). Bildungsstandards Mathematik: konkret. Berlin: Cornelsen-Scriptor.

Boistrup, L. B. (2010). Assessment discourses in mathematics classrooms: A multimodal social semiotic study (Doctoral dissertation). Stockholm, Sweden: Stockholm University.

Bosch, M., \& Gascón, J. (2014). Introduction to the anthropological theory of the didactic (ATD). In A. Bikner-Ahsbahs \& S. Prediger (Eds.), Networking of theories as a research practice in mathematics education (pp. 67-83). Cham: Springer. 
Bråting, K., Hemmi, K., Madej, L., \& Röj-Lindberg, A.-S. (2016). Towards research-based teaching of algebra-Analyzing expected student progression in the Swedish curriculum for grades 1-9. Paper presented at the 13th International Congress on Mathematics Education, ICME-13, Hamburg, 24-31 July 2016.

Brekke, G. (1994). KIM - Kvalitet i matematikkundervisning [KIM-Quality in mathematics education]. Tangenten, 5(1), 4-8.

Brekke, G. (2002). Introduksjon til diagnostisk undervisning i matematikk [Introduction to diagnostic teaching in mathematics]. Oslo: Læringssenteret.

Brousseau, G. (1997). The theory of didactical situations in mathematics: Didactique des mathématiques, 1970-1990 (N. Balacheff, M. Cooper, R. Sutherland, \& V. Warfield, Eds. \& Trans.). Dordrecht: Kluwer.

Dahl, H., Klemp, T., \& Nilssen, V. (2017). Collaborative talk in mathematics-Contrasting examples from third graders. Education 3-13. International Journal of Primary, Elementary and Early Years Education, 1-13. https://doi.org/10.1080/03004279.2017.1336563.

Dyrvold, A., Bergqvist, E., \& Österholm, M. (2015). Uncommon vocabulary in mathematical tasks in relation to solution frequency and demand of reading ability. Nordic Studies in Mathematics Education, 20(1), 5-31.

Enge, O., \& Valenta, A. (2015). Student teachers' work on reasoning and proving. In H. Silfverberg, T. Kärki, \& M. S. Hannula (Eds.), Nordic research in mathematics education: Proceedings of NORMA14, Turku, June 3-6, 2014 (pp. 61-70). Turku: University of Turku.

Engström, A., \& Magne, O. (2010). From Henschen to Middletown mathematics: Swedish research on low achievement in mathematics. In B. Sriraman, et al. (Eds.), The first sourcebook on Nordic research in mathematics education (pp. 333-345). Charlotte, NC: Information Age Publishing.

Ernest, P. (2000). Why teach mathematics? In S. Bramall \& J. White (Eds.), Why learn maths? (pp. 1-14). London: Institute of Education.

Fauskanger, J. (2015). Challenges in measuring teachers' knowledge. Educational Studies in Mathematics, 90, 57-73.

Furinghetti, F., \& Giacardi, L. (Eds.). (2012). The first century of the International Commission on Mathematical Instruction (1908-2008). History of ICMI. http://www.icmihistory.unito.it.

Fyhn, A. B. (2010). Sámi culture and algebra in the curriculum. In V. Duran-Guerrier, S. SouryLavergne, \& F. Arzarello (Eds.), Proceedings of the Sixth Congress of the European Society for Research in Mathematics Education (pp. 489-498). Lyon: INRP and ERME.

Fyhn, A. B., Meaney, T. J., Nystad, K., \& Nutti, Y. J. (2017). How Sámi teachers' development of a teaching unit influences their self-determination. In T. Dooley \& G. Gueudet (Eds.), Proceedings of the Tenth Congress of the European Society for Research in Mathematics Education (pp. 1481-1488). Dublin: DCU and ERME.

Gjone, G. (2013). NOMAD-Nordic studies in mathematics education. The first eight years. In B. Grevholm, P. S. Hundeland, K. Juter, K. Kislenko, \& P.-E. Persson (Eds.), Nordic research in didactics of mathematics: Past, present and future (pp. 182-198). Oslo: Cappelen Damm Akademisk.

Gravemeijer, K. (2007). Emergent modelling as a precursor to mathematical modelling. In W. Blum, P. L. Galbraith, H.-W. Henn, \& M. Niss (Eds.), Modelling and applications in mathematics education. The 14th ICMI Study (pp. 137-144). New York, NY: Springer.

Gravesen, K. F., Grønbæk, N., \& Winsløw, C. (2017). Task design for students’ work with basic theory in analysis. The cases of multidimensional differentiability and curve integrals. International Journal of Research in Undergraduate Mathematics Education, 3(1), 9-33.

Grevholm, B. (2005). The Nordic graduate school in mathematics education-A growing network. Nordic Studies in Mathematics Education, 10(2), 61-62.

Grevholm, B. (2007). The Nordic graduate school in mathematics education. Nordic Studies in Mathematics Education, 12(4), 79-83.

Grevholm, B. (2008). The Nordic graduate school in mathematics education-Planning for the future. Nordic Studies in Mathematics Education, 13(2), 93-98. 
Hiebert, J., \& Lefevre, P. (1986). Conceptual and procedural knowledge in mathematics: An introductory analysis. In J. Hiebert (Ed.), Conceptual and procedural knowledge: The case of mathematics (pp. 1-27). Hillsdale, NJ: Lawrence Erlbaum.

Hodgson, B. R., \& Niss, M. (2018). ICMI 1966-2016: A double insiders' view of the latest half century of the International Commission on Mathematical Instruction. In G. Kaiser, H. Forgasz, M. Graven, A. Kuzniak, E. Simmt, \& B. Xu (Eds.), Invited lectures from the 13th International Congress on Mathematical Education (pp. 229-247). Cham: Springer.

Hodgson, B. R., Rogers, L. F., Lerman, S., \& Lim-Teo, S. K. (2013). International organisations in mathematics education. In M. A. Clements, A. J. Bishop, C. Keitel, J. Kilpatrick, \& F. K. S. Leung (Eds.), Third international handbook of mathematics education (pp. 901-947). New York, NY: Springer.

Jaworski, B. (2006). Theory and practice in mathematics teaching development: Critical inquiry as a mode of learning in teaching. Journal of Mathematics Teacher Education, 9, 187-211.

Jaworski, B., \& Goodchild, S. (2006). Inquiry community in an activity theory frame. In J. Novotná, H. Moraová, M. Krátká, \& N. Stehliková (Eds.), Proceedings of the 30th Conference of the International Group for the Psychology of Mathematics Education (Vol. 3, pp. 353-360). Prague: PME.

Johansson, B. (1986). Sveriges förste forskare i matematikdidaktik [The first researcher in didactics of mathematics in Sweden]. Nämnaren, 12(3), 6-10.

Johansson, B. (1993). En ny nordisk forskningstidskrift [A new Nordic research journal]. Nordic Studies in Mathematics Education, 1(1), 4-7.

Johansson, M., Lange, T., Meaney, T., Riesbeck, E., \& Wernberg, A. (2014). Young children's multimodal mathematical explanations. ZDM-The International Journal on Mathematics Education, 46, 895-909.

Juter, K. (2006). Limits of functions-University students' concept development (Doctoral dissertation). Luleå, Sweden: Luleå University of Technology.

Juter, K. (2017). University students' understandings of concept relations and preferred representations of continuity and differentiability. In T. Dooley \& G. Gueudet (Eds.), Proceedings of the Tenth Congress of the European Society for Research in Mathematics Education (pp. 2121-2128). Dublin: DCU and ERME.

Kilpatrick, J. (1992). A history of research in mathematics education. In D. A. Grouws (Ed.), Handbook of research on mathematics teaching and learning (pp. 3-38). New York, NY: Simon \& Schuster Macmillan.

Kilpatrick, J., Swafford, J., \& Findell, B. (Eds.). (2001). Adding it up: Helping children learn mathematics. Washington, DC: National Academy Press.

Kirke- og undervisningsdepartementet. (1974). Mфnsterplan for grunnskolen 1974 [National Curriculum for compulsory school 1974]. Oslo: Author.

Kjærnsli, M., \& Jensen, F. (Eds.). (2016). Stø kurs. Norske elevers kompetanse i naturfag, matematikk og lesing i PISA 2015 [Steady course. Norwegian pupils' competence in mathematics, science and reading]. Oslo: Universitetsforlaget.

Klein, F. (1872). Vergleichende Betrachtungen über neuere geometrische Forschungen. Erlangen: Andreas Deichert. http://www.deutschestextarchiv.de/book/view/klein_geometrische_1872?p= 13.

Kozulin, A. (1985). Vygotsky in context. In L. Vygotsky (Ed.), Thought and language (A. Kozulin, Ed. \& Trans.) (pp. $x i-l v i)$. Cambridge, MA: The MIT Press.

Kruse, A. (2010). Åskådningsmatematik [Visual mathematics]. Stockholm: Nordsteds. (Original work published 1910)

Leder, G. C., Brandell, G., \& Grevholm, B. (2004). The Swedish graduate school in mathematics education. Nordic Studies in Mathematics Education, 9(2), 165-182.

Linné, A. (2010). Lärarutbildning $i$ historisk belysning [Teacher education in historic light] Resource document. Lärarnas historia [The history of teachers]. http://www.lararnashistoria.se/ article/lararutbildningens_historia. 
Lithner, J. (2000). Mathematical reasoning in task solving. Educational Studies in Mathematics, $41,165-190$.

Lithner, J. (2008). A research framework for creative and imitative reasoning. Educational Studies in Mathematics, 67, 255-276.

Lithner, J. (2017). Principles for designing mathematical tasks that enhance imitative and creative reasoning. ZDM-Mathematics Education, 49, 937-950.

Magne, O. (1958). Dyskalkuli bland folkskoleelever [Dyscalculia among primary school pupils]. Gothenburg: University of Gothenburg.

Marton, F. (1981). Phenomenography-Describing conceptions of the world around us. Instructional Science, 10, 177-200.

Marton, F., \& Booth, S. (1997). Learning and awareness. Mahwah, NJ: Lawrence Erlbaum.

Måsøval, H. S. (2011). Factors constraining students' appropriation of algebraic generality in shape patterns: A case study of didactical situations in mathematics at a university college (Doctoral dissertation). Kristiansand, Norway: University of Agder.

Mellin-Olsen, S. (1977). Laring som sosial prosess [Learning as a social process]. Oslo: Gyldendal Norsk Forlag.

Mellin-Olsen, S. (1987). The politics of mathematics education. Dordrecht: D. Reidel Publishing Company.

Mellin-Olsen, S. (1991). Hvordan tenker laerere om matematikkundervisning? [How do teachers think about the teaching of mathematics?] Bergen: Bergen College of Education.

Mellin-Olsen, S. (1993). Et nordisk forskningstidsskrift for matematikk fagdidaktikk [A Nordic research journal for didactics of mathematics]. Tangenten, 4(2), 18.

Mellin-Olsen, S. (2009). Oppgavediskursen i matematikk [The exercise discourse in mathematics]. Tangenten, 20(2), 2-7.

Munthe, E., Bjuland, R., \& Helgevold, N. (2016). Lesson study in field practice: A time-lagged experiment in initial teacher education in Norway. International Journal for Lesson and Learning Studies, 5(2), 142-154.

Niss, M. (2013). Dominant study paradigms in mathematics education research-For better and for worse. Global trends and their impact on Nordic research. In B. Grevholm, P. S. Hundeland, K. Juter, K. Kislenko, \& P.-E. Persson (Eds.), Nordic research in didactics of mathematics: Past, present and future (pp. 395-408). Oslo: Cappelen Damm Akademisk.

Niss, M., \& Højgaard, T. (2011). Competencies and mathematical learning. Ideas and inspiration for the development of mathematics teaching and learning in Denmark. Roskilde: Roskilde University.

Niss, M., \& Jensen, T. H. (2002). Kompetencer og matematiklaring. Ideer og inspirasjon til udvikling af matematikundervisning i Danmark. Copenhagen: Undervisningsministeriet.

Nissen, G. (1993). Nordisk forskernetverk - Initiativet matematikundervisning og demokrati [Nordic network of researchers-the initiative mathematics education and democracy]. Nordic Studies in Mathematics Education, 1(1), 62-65.

Nissen, G. (1994). Matematikundervisning i en demokratisk kultur [Mathematics education in a democratic culture]. Nordic Studies in Mathematics Education, 2(2), 58-69.

Nordisk udredningsserie. (1967). Nordisk skolmatematik [Nordic school mathematics]. Stockholm: Esselte AB.

Norén, E. (2015a). Agency and positioning in a multilingual mathematics classroom. Educational Studies in Mathematics, 89, 167-184.

Norén, E. (2015b). Positioning of girls and boys in a primary mathematics classroom. In H. Silfverberg, T. Kärki, \& M. S. Hannula (Eds.), Nordic research in mathematics education: Proceedings of NORMA14, Turku, June 3-6, 2014 (pp. 361-370). Turku: Finnish Research Association for Subject Didactics.

OEEC. (1961). New thinking in school mathematics. Paris: Author.

Österholm, M., \& Bergqvist, E. (2013). What is so special about mathematical texts? Analyses of common claims in research literature and of properties of textbooks. ZDM-The International Journal on Mathematics Education, 45(5), 751-763. 
Palmér, H. (2013). To become — or not to become-A primary school mathematics teacher (Doctoral dissertation). Växjö, Sweden: Linnaeus University.

Pehkonen, E. (Ed.). (1995). NORMA-94 Conference. Proceedings of the Nordic Conference on Mathematics Teaching (NORMA-94) in Lahti 1994. Helsinki: University of Helsinki.

Pehkonen, E. (2012). Research on mathematics beliefs. The birth and growth of the MAVI group in 1995-2012. Nordic Studies in Mathematics Education, 17(3-4), 7-22.

Pettersson, A., \& Boistrup, L. B. (2010). National assessment in Swedish compulsory school. In B. Sriraman, et al. (Eds.), The first sourcebook on Nordic research in mathematics education (pp. 373-385). Charlotte, NC: Information Age Publishing.

Prytz, J. (2018). The New Math and school governance: An explanation of the decline of the New Math in Sweden. In F. Furinghetti \& A. Karp (Eds.), Researching the history of mathematics education: An international overview (pp. 189-216). Cham: Springer.

Prytz, J., \& Karlberg, M. (2016). Nordic school mathematics revisited-On the introduction and functionality of New Math. Nordic Studies in Mathematics Education, 21(1), 71-93.

Rønn, E. (1986). Matematikundervisningen i folkeskolen 1958-1975 [Mathematics teaching in the primary school 1958-1975]. In Uddannelseshistorie 1986, Årbog for Selskabet for Skole- og Uddannelseshistorie (pp. 66-94).

Rønning, F. (2017). Influence of computer-aided assessment tools on ways of working with mathematics. Teaching Mathematics and its Applications, 36(2), 94-107.

Rønning, F., \& Strømskag, H. (2017). Entering the mathematical register through evolution of the material milieu for classification of polygons. In T. Dooley \& G. Gueudet (Eds.), Proceedings of the Tenth Congress of the European Society for Research in Mathematics Education (pp. 1348-1355). Dublin: DCU and ERME.

Runesson, U., \& Kullberg, A. (2010). Learning from variation: Differences in learners' ways of experiencing differences. In B. Sriraman, et al. (Eds.), The first sourcebook on Nordic research in mathematics education (pp. 299-317). Charlotte, NC: Information Age Publishing.

Rystedt, E., Kilhamn, C., \& Helenius, O. (2016). Moving in and out of contexts in collaborative reasoning about equations. Journal of Mathematical Behavior, 44, 50-64.

Sayers, J., Andrews, P., \& Boistrup, L. B. (2016). The role of conceptual subitising in the development of foundational number sense. In T. Meaney, O. Helenius, M. L. Johansson, T. Lange, \& A. Wernberg (Eds.), Mathematics education in the early years: Results from the POEM2 conference, 2014 (pp. 371-396). Cham: Springer.

Sfard, A. (1991). On the dual nature of mathematical conceptions: Reflections on processes and objects as different sides of the same coin. Educational Studies in Mathematics, 22, 1-36.

Skemp, R. R. (1971). The psychology of learning mathematics. Harmondsworth: Penguin Books.

Skemp, R. R. (1976). Relational understanding and instrumental understanding. Mathematics Teaching, 77, 20-26.

Skog, K. (2014). Power, positionings and mathematics. Discursive practices in mathematics teacher education (Doctoral dissertation). Stockholm, Sweden: Stockholm University.

Skott, J. (2013). Understanding the role of the teacher in emerging classroom practices: Searching for patterns of participation. ZDM-The International Journal on Mathematics Education, 45(4), $547-559$.

Skott, J. (2017). Towards a participatory account of learning to teach. In A. Quortrup \& M. Wiberg (Eds.), Dealing with conceptualisations of learning —Learning between means and aims in theory and practice (pp. 133-143). Rotterdam: Sense.

Skovsmose, O. (1994). Towards a philosophy of critical mathematics education. Dordrecht: Kluwer.

Skovsmose, O. (2001). Landscapes of investigation. ZDM-Mathematics Education, 33(4), $123-132$.

Skovsmose, O. (2002). Matematiken er hverken god eller dårlig - og da slet ikke neutral [Mathematics is neither good nor bad-But far from neutral]. Tangenten, 13(3), 22-26.

Skovsmose, O. (2003). Undersøgelseslandskaber [Landscapes of investigation]. In O. Skovsmose \& M. Blomhøj (Eds.), Kan det virkelig passe?- om matematiklaring [Could it really be like that?-On the learning of mathematics] (pp. 143-157). Copenhagen: L\&R Uddannelse. 
Skovsmose, O. (2010). Critical mathematics education: In terms of concerns. In B. Sriraman, et al. (Eds.), The first sourcebook on Nordic research in mathematics education (pp. 671-682). Charlotte, NC: Information Age Publishing.

Solvang, R., \& Mellin-Olsen, S. (1978). Matematikk fagmetodikk [Mathematics subject methods]. Stabekk: NKI-forlaget.

Strässer, R. (2005). An overview of research on teaching and learning mathematics. Stockholm: Vetenskapsrådet.

Sumpter, L., \& Hedefalk, M. (2015). Preschool children's collective mathematical reasoning during free outdoor play. The Journal of Mathematical Behavior, 39, 1-10.

Telhaug, A. O., \& Mediaas, O. A. (2003). Grunnskolen som nasjonsbygger. Fra statspietisme til nyliberalisme [The role of compulsory school in building the nation. From state pietism to new liberalism]. Oslo: Abstrakt Forlag AS.

Valero, P. (2017). Mathematics for all, economic growth, and the making of the citizen-worker. In T. S. Popkewitz, J. Diaz, \& C. Kirchgasler (Eds.), A political sociology of educational knowledge: Studies of exclusions and difference (pp. 117-132). New York, NY: Routledge.

Van Bommel, J., \& Liljekvist, Y. (2016). Teachers' informal professional development on social media and social network sites: when and what do they discuss? Paper presented at the ERME-topic conference: Mathematics teaching, resources and teacher professional development, Humboldt-Universität, Berlin. https://hal.archives-ouvertes.fr/ETC3/public/Full_Download.pdf.

Van Bommel, J., \& Palmér, H. (2016). Young children exploring probability: With focus on their documentations. Nordic Studies in Mathematics Education, 21(4), 95-114.

Winsløw, C. (2009). Nordic research in mathematics education: From NORMA08 to the future. In C. Winsl $\varnothing \mathrm{w}$ (Ed.), Nordic research in mathematics education: Proceedings from NORMA08, Copenhagen, April 21-April 25, 2008 (pp. 1-4). Rotterdam: Sense Publishers.

Open Access This chapter is distributed under the terms of the Creative Commons Attribution 4.0 International License (http://creativecommons.org/licenses/by/4.0/), which permits use, duplication, adaptation, distribution and reproduction in any medium or format, as long as you give appropriate credit to the original author(s) and the source, a link is provided to the Creative Commons license and any changes made are indicated.

The images or other third party material in this chapter are included in the work's Creative Commons license, unless indicated otherwise in the credit line; if such material is not included in the work's Creative Commons license and the respective action is not permitted by statutory regulation, users will need to obtain permission from the license holder to duplicate, adapt or reproduce the material. 